\title{
From materiality to system
}

\author{
Louis Armand \\ Department of English and American Studies, Charles University, \\ Nam. J. Palacha 2, 11638 Praha 1, Czech Republic. \\ e-mail: lazarus@praha1.ff.cuni.cz
}

\begin{abstract}
This paper seeks to address the relation of materiality to structure and phenomena of signification or semiosis. It examines the logical consequences of several major lines of argument concerning the status of semiosis with regards to the human or broadly "organic" life-world and to the "zero degree" of base materiality — from Peirce to Lotman and Sebeok — and questions the classificatory rationale that delimits semiosis to the exclusion of a general treatment of dynamic systems. Recent investigations into neurosemiotics have provided salient arguments for the need to treat semiosis as a characteristic of systems in general, and to establish a more transverse understanding of signifiability upon the basis of what makes dynamic structures, as such, possible.
\end{abstract}

\section{Introduction: Why is there structure rather than chaos?}

Such questions bring into view a certain habit of reason which has accustomed us to regard the world in terms of a conceptual division between the inert and the animate, matter and mind, substance and form - indeed, to regard it as something like a Byzantine vista of categories, types, and classes, whose bifurcations and taxonomies appear, from moment to moment, as seemingly real and incontravertable as the "great chain of being" on the eve of the Lamarckian revolution, while any perceived ambivalence to rigid denomination has routinely been suppressed "for the sake of meaning". As various commentators have noted, "humans seem equipped by the structure of the brain to perceive patterns, and the trick has survival value, but this does not prove that all the patterns we perceive are really there" (Everdell 1997: 346), nor does it prove that those inimical to particular modes of 
theorisation do not, therefore, exist. Categories, types and classes are themselves derived statistical descriptions of stochastic processes whose "emergent" regularities or patterns have too often been mistaken for an order of things or immutable schema. Their symmetry has, up until recent times, defined the limiting epistemological criteria both of philosophical and scientific discourse, whose character (dialectic, dualistic, oppositional) can more properly be described as metaphorical or analogical.

While a great deal has been written about dialectics, dualism and binary opposition, there still remains the task of accounting for the inaugurating metaphoricity that can be said to condition each of these modes of thought. By metaphoricity it is meant a certain "mechanism" of equivalence, vested in an otherwise arbitrary relation invoked between "unlike" and "uncommunicating" terms, and therefore formally paratactic or discontinuous. This mechanism may be said to be founded upon a predisposition of metaphor towards a delineation of its objects in terms of structural equivalence and inequivalence (and only consequently semantic equivalence). That is to say, along an axis of suppressed ambivalence. The ambivalent quality of this axis comes more clearly into view once we recognise its ostensibly arbitrary function in defining an "oppositional" relationship between paired terms, and a "homological" one between terms arranged on either side of it. Such ambivalence, in light of the metaphorical schema organised around it, acquires the appearance of something like a metonymic recursion, in that it describes a certain asymmetrical relation across contiguity. That is to say, the so-called oppositional terms are either mutually determinate or partial - meaning that the one inclines to an "excluded" or "detached" characteristic of the other.

It is precisely in the co-implied structures of metaphor and metonymy - of implication and co-implication - that we encounter ambivalence as an engine of possibility, by means of which supposedly inert matter assumes the characteristic of a sign, such that - for example - we may consider signification not as a process that is retrospectively projected upon the universe - i.e. as a rationalistic mirrorfantasy - or "modelled" in our own image (vis-à-vis the symmetry or synonymy of likeness), but rather as a process that necessarily accompanies the most elementary material relations which, posed as "oppositional", "correlative", or "complementary", imply some aspect of formal communication. Such communication, however, must be dis- 
tinguished from the assumptions of "analogical" correspondence (similarity, likeness, resemblance), so that when we speak of possibility we mean something contingent upon ostensibly material and probabilistic constraints, but which also exceeds and envelopes those constraints (metaphor, metonymy); indeed, which would in fact constitute their very condition. Consequently, our initial question may be reformulated as: How is it, that even at the most basic level, matter appears to be bound up with the very nature of structure, of structurality and of structure's immanent possibility?

This question, or series of questions, has given rise within the study of sign systems to analogous questions which, on the surface at least, approach the problem from the opposite side, in terms such as: "Can the essence of life - or, at least, our concept of life - be understood in a semiotic framework?" (Luure 2002: 315). On the one hand, a base, inert materiality; while on the other, life-processes, dynamic systems, or mechanisms of reflection; posed against an axis of structuration which, both nominally and yet in some sense equally "essentially," is therefore also an axis of signification, or of what we might call "sign operations" or semiosis. This apparent opposition sketched here in a merely provisional, though also conventional, outline - is itself a characteristic of a certain axial mode of thinking (symmetrical, asymmetrical) which, even if not in purely "value" terms, obtains its impetus by arranging its objects across a differential gradient - according to which certain tendencies are schematised in relational or transferential terms (as a movement, for example, from materiality to systematicity) desribing what we might call a formal immanence.

To tend, however, will have always implied a movement of continuity versus discontinuity; such as is implied in a system of arbitrarily defined difference, for example, or as represented in the paratactic structures of metaphor and metonymy, and which is effectively masked by the assumption - retrospectively supplied — of a latent similarity, synonymy or formal "symmetry". This quasi-progressivist notion, with its neo-Platonistic undertones of an "en te physei" (the immanence attributed to paradeigmata as the "future forms of things" latent within any process of structuration, including the naturalisation of forms into species in Aristotle's schema) - or equally of a transmutation of base matter into something like a consciousness (however necessarily conjectural its character) — ought not, however, to be per- 
ceived as merely a doctrinal or ideological caprice. Insofar as we may say that "binary structures" obtain within material relations — that materiality tends to structurality — or that material relations are themselves fundamentally axial or "ambivalent," only presupposes an opposition or value-relation on the basis of a "signifying" function (and not of a "representation" or "model-image" as such), and it would therefore seem that the overriding concern to which our initial questions refer is how we are to "locate" a signifying function within, or across, an "originary" binary relation, in advance of any semantic schematisation. That is to say, in advance of any assumption of meaning other than the fact of this relation itself. But is such a thing possible?

In Global Semiotics (2001), Thomas Sebeok attempts to frame this problem in terms of a globalised view of material structures that, to a limited extent, re-echoes Gregory Bateson's ecologies of mind and parallels Juri Lotman's theory of semiospheres, in attempting to "extend" semiotic concepts into the "vitalistic' or biological realm. The logical implications of Sebeok's thesis, however, can be seen as countering Sebeok's own assumption that a discourse of biosemiotics can only be founded upon a metaphorical approximation of sign structures to living systems. The structural logic of biosemiotic systems nevertheless directly implies structural logics characteristic of non-organic "dynamic systems" (or what might equally be termed dissipative systems, according to which entropy would describe a common characteristic of both so-called life systems and non-organic dynamic systems) and thus points us towards a "literalised" understanding of semiotics in its global implications. One of these implications being that, founded upon a purely material basis, semiosis, or sign operations, ultimately presuppose what we call a phenomenon of consciousness, and hence of agency - and consequently that agency must be vested first and foremost in the very materiality of structure, and thus also be considered immanent to it, rather than representing a quality externally derived or somehow instantiated by way of external processes - i.e. applied to it - or derived from some autonomous model-image. Likewise, the concept of dynamic sign systems, organ- 
ised around an "axis of ambiguity" or structural recursion, cannot simply be reduced to an externally supplied impetus (vis-à-vis Newton's law). As with physical systems, the recursive mechanisms to which we assign the term agency remain ambiguous with regard to the distinction, for example, between "energy" and "matter" (energeīa and prāgmata), even if such mechanisms remain subject to the tendency of all closed systems to dissipate. It remains that the "communication" of the energy-matter relation (or ratio) requires a prior structural possibility, such that we can speak of a system as such and not merely of an "isolated effect".

Interpreting along similar but restricted lines, according to the limited case-model of biosemiotics, Sebeok postulates that "two cardinal and reciprocal axioms of semiotics" must therefore be:

(1a) The criterial mark of all life is semiosis; and (1b) Semiosis presupposes life $[\ldots]$. Further semiosic unfoldings - such as the genesis of ordered oppositions like self/other, inside/outside, and so forth - derive from, or are corollaries of, the above pair of universal laws. (Sebeok 2001: 10-11)

Drawing upon the biological theories of Jakob von Uexküll, the lifeworld is described by Sebeok as a type of biotext, not simply in the sense that living systems are affective of signification, but rather that they devolve - as systems - upon a processual network of sign operations. Sebeok argues:

The aim of biosemiotics is to extend the notions of general semiotics to encompass the study of semiosis and modeling in all species. The premise which guides biosemiotics is, in fact, that the forms produced by a specific species are constrained by the modeling system(s) which has evolved from its anatomical constitution. The aim of biosemiotics is to study not only the species belonging to one of the five kingdoms, Monera, Protocista, Animalia, Plantae, and Fungi, but also their hierarchically developed component parts, beginning with the cell, the minimal semiosic unit [...]. In a phrase, the target of biosemiotics is the semiosic behaviour of all living things. (Sebeok, Danesi 2000: 15)

Once again the concept of structural agency emerges here as an instrumental action in the tendency from "anatomical constraint" to "modelling system" to "semiosis". The question remains as to how it is possible to abstract semiosis from this evolutionary process? Equally, if semiosis is to be conditioned by an effect or phenomenon of agency, how is an assumption of agency to take place other than as 
an evolution within and as this functional, constitutive anatomy - i.e. describing "emergent" regularities — such that its "constraints" remain immanent, rather than as an autonomous set of codes or paradeigmata upon which a semiotic condition may be modelled or according to which its "form" may be said to be determined. Distinguishing between latency and immanence, the complementarity of constraint and structurality ("anatomic constitution") are what define semiosis as the very condition and possibility of agency, and not vice versa as the organicist argument would suggest.

If we are to speak of agency as a non-linear, "causal circuit" of material constraints upon which "cognitive action" devolves — vis-à-vis the trope of semiosis - and not the contrary, then it is a matter of reorientating Sebeok's biosemiotic model towards a properly global semiotics founded upon a concept of discursive materiality, in its literal and no longer "metaphorical" sense. This requires that we examine the implications of C. S. Peirce's contention that the universe as such is characterised (though not exclusively) by sign operations, and Margaret Mead's re-definition of semiotics in 1962 as "patterned communication in all its modalities". This would require that we firstly arrive at an understanding of what such concepts as "universal," "sign operation" and "communication" might require by way of reformulation if we are to pose them in strictly material terms - that is to say, in terms independent of assumptions of human agency or of biological vitalism (zoösemiotics, anthroposemiotics and phytosemiotics). And this would mean accounting for the operations of signs as such - an accounting which would necessarily draw into question Sebeok's insistence that Saussure's "linguistic paradigm" represents a distortion of natural signifying.

John Deely paraphrases Sebeok's argument as being founded upon a distinction "between language, as having in itself nothing to do with communication but which, through exaption, gives rise to linguistic communication as species-specifically human, and communication, which is a universal phenomenon of nature" (Deely 2004). In this way Sebeok is seen to reject the notion that animal species other than humans may be possessed of language, or at least of "linguistic commu- 
nication". Yet insofar as communication presupposes something other than random, singular events of "transmission" - although this in itself would require elaborate definition - the question remains as to what "linguistic communication" could entail in distinction from communication in its universal sense, since any form of structuration or sign operation must be given to require, for example, some type of syntactic and broadly signifying "function," and that such functions must be generalisable (as a function of the possible) across an arbitrarily defined field of potential "signs". And if "universal" conditions are to obtain vis-à-vis communication, from where do such conditions arise if they are not also to be attributed to "linguistic communication," on the one hand, and to the material states of dynamic (non-life) systems on the other?

Indeed, the opposition here between "communication, which is a universal phenomenon of nature" and "linguistic communication", reveals itself to be nothing other than a restatement of the natureartifice (physis-technē) dualism that has reasserted itself at different points in the history of Western thought, and which more recently has manifested itself in terms of natural and artificial languages, and natural and artificial intelligence. As a sub-class of communication, "linguistic communication" is presented as a mere "species-specifically human" prosthesis. In other words, a supplementary mode or model of communication, vested in a formal definition of language as artefactual (the specifically human techniques or technologies of speech and writing, for example, as opposed to a species-aspecific "semiosis"). The distinction is based in part upon the assumption of agency, such that "language" is defined as a particular use to which the phenomenon of communication is put: that it is a utility, an addition or extension, and thus bears no relation to ("has nothing to do with") the underwriting conditions of communication in its universal aspect.

The question immediately arises as to how language, as a prosthesis of communication, is possible if its operations are not somehow vested already in those of communication as such. By implication, this question extends also to the limiting claims of biosemiotics that communication be viewed as "a universal phenomenon of nature" solely to the extent that it relates to the operations of life-systems. Simplifying, this question becomes: upon what are the operations of life-systems founded if not upon a general condition of materiality, upon which the possibility of sign operations must also devolve? In other words, are 
not the assumptions about "nature" and natural communication in fact already presupposed in a generalised techne — what we might go so far as to characterise as the very techne of possibility itself - as a function not of derivation from "anatomical constraints" (or "modelling systems," which by definition already function semio-mimetically), but of an architectonics of constraint (material, probabilistic), which thereby is regarded as programming the general semiotic apparatus?

If so, the "basic unit" of semiotic systems cannot, contrary to Sebeok's insistence, be meaningfully defined (analogically or otherwise) in terms of the biological "cell," which in itself - even as the ultimate element of organic structures - is already a complex of micro- and macro-scale molecular events. The "agency" (or bio-technics) of cell division or propagation is already prefigured in the "agency" of dynamic systems contained within it, and indeed sustaining and superseding it - whether these involve enzymic transcriptions or atomic states. If we assume a literal significance to Peirce's threefold condition of semiosis (that any sign operation presupposes a relation of two elements to a third element) (Peirce 1955: 99-100), then we may posit the "basic unit" of semiotics as any mediated binary relation - i.e. satisfying the minimal conditions for a dynamic system. Negatively defined, semiosis is thus a measure of entropy, insofar as it implies even the most rudimentary and minimal of system dynamics - as in Bateson's "difference that makes a difference" (Bateson 1973: 428). Hence, in place of the limiting sense of semiosis presupposing "life," it is necessary to posit a more general notion of semiosis - one properly consistent with the logic of a "communication, which is a universal phenomenon" - describing material, and fundamentally technical, processes of transmission, propagation and dissipation.

\section{3}

The dilation of materiality in the "figure" of communication, language or sign systems, brings into view a fundamental incongruity in the logic of biosemiotics in the assumption of a life-principle or biological agency as the determining condition of semiosis. Sebeok's two "cardinal and reciprocal axioms of semiotics" reflect the tendency of a closed semiotic system towards what we might call the vertigo of self- 
representation, according to which semiosis is "constrained" by its own "modelling system", thus succumbing to a reductio ad infinitum. Moreover, the arbitrary distinction between the sign-mechanics of organic systems and the signifying possibility of material relations per se, implies a logic of exceptions whereby biosemiotics merely reinscribes a certain analogical privilege - i.e. that the figure of agency must in all accounts remain distinguishable from the "condition" of base matter, as in fact the determining limit of that class of entity that culminates in man.

The genesis of "ordered oppositions" underwriting Sebeok's claim to certain "universal laws" of semiotics is thus not universal at all but based upon a foundation of behavioural and bio-mimetic assumptions. By behavioural and bio-mimetic it is above all meant analogical, in the sense that the genesis of "ordered oppositions" is said to resemble the formal structurality innate to semiotic systems as such. Hence, that the discourse of semiotics is effectively modelled upon the organisation of its primary objects, thereby acquiring an aura of scientific validity. Such claims to validation, however, belie a particular asymmetry in the relation between biosemiotics and its object, on the one hand, and the general discursiveness of sign structures on the other. An asymmetry, moreover, reflected in the very discourse of biosemiotics which both characterises the very impetus of semiosis defined within that discourse, but also - and of necessity - points beyond its limiting criteria towards a general condition of semiosis (implied by Lotman's semiosphere); one which is radically non-analogical, but which describes the prior possibility of analogical structures; one which is not representable within the discourse of biosemiotics, but which rather describes an horizon of representability. In this we may recognise a fundamental dependency upon a technē of metaphoric substitution and metonymic forethrow, or of what we call "equivalence across contiguity".

Re-echoing Claude Lévi-Strauss' studies in structural anthropology, Lotman (like Sebeok) derives a logic of "ordered opposition" on an analogical rather than properly structural or material basis, founded upon culturally (or "ideologically") articulated assumptions about signifiability. This points to both an explicit and hidden anthropomorphism within the discourse of biosemiotics, which - despite its universalism - posits the "asymmetry" of semiotic systems (what we 
might call their dynamic gradient) in species-specific - and hence analogical - terms. According to Lotman:

The asymmetry of the human body is the anthropological basis for its semioticisation: the semiotics of right and left are found just as universal in all human cultures as the opposition top and bottom. And the fundamental asymmetry of male and female, living and dead, are just as widespread. The living/dead opposition involves the opposition of something moving, warm, breathing, to something immobile, cold, not breathing (the belief that cold and death are synonyms is supported by an enormous number of texts from different cultures, and just as common is the identification of death with turning to stone [...] (Lotman 1990: 133)

This preoccupation with the "orientational" logic of ordered opposition - or of oppositional pairs (or binaries) - founded here upon a process of textual induction with its appeals to cultural and empirical facticity, belies a systematic dependence upon an oppositional logic that is purely formal, normative, and metaphysically "grounded". It is in accordance with such a logic that we encounter the continuing distinction between such terms as animate-inanimate, nature-artifice, body-mind, sensible-intelligible, and so on, not to speak of the endless series of cognate oppositions between purely qualitative terms, defining a network of associated values from which the discourse of biosemiotics is in no way exempt.

Disagreement with this tendency to a limited, doctrinal approach to semiotic phenomena, has provoked a number of corrective hypotheses. One such is represented by the emergent discourse of neurosemiotics, which focuses upon the material, neurological conditions of what we call communication, affected not on biologically causal grounds, but rather in terms of a general state of probabilistic intermediation. According to this view:

If we understand semiosis to be an organising principle of all manner of signexchange, then the operational processes enabling signification from receptor cell to interneuron to effector cell and the processes enabling signification across the meta-systems of biological organisation (cell, pathway, network, organ, system, body proper) and across levels of awareness (network signification, body signification, mental signification) reveal themselves as systemic 
parts in a lawful, interactive continuum - a view of mind and body that allows us to transcend the intransigent dualism of contemporary neuroscience [...]. (Favareau 2002: 80)

In contrast to the analogical "modelling systems" characteristic of Sebeok's "global semiotics", the enquiry into semiosis as an "organising principle of all manner of sign-exchange" — but above all concerned with the "principles by which the emergence of mental representation from neuronal electro-chemical signal transduction is even possible" (Favareau 2002: 66) - points to the necessity of a fundamentally material understanding of the mechanisms of reflexivity, representability, and mechanical agency as a basis for defining cognitive processes (or, equally, "organic" processes).

The mediational aspect of all signifying structures — with its analogies to mind, consciousness or thought - has tended to become obscured in the investigation of what might be called signifying materiality and those processes by which, to reformulate Donald Favareau's expression, the apparent "emergence" of sign structures from base matter is deemed possible. The problem here, however, is not to do with the "advent" of semiosis, but with its possibility in the first place. In other words, how it is that what we call "base matter" appears to be already inscribed within a field of signifying possibility in which semiotic system-effects are determined probabilistically according to a transverse relation between local events and global states, and vice-versa (where "system" implies a continuity effect underwritten by networks of micro-macro dis-continuity)? Such transverse relations or "non-linear circuits" (as between and across Favareau's "meta-systems") affect a refiguration of what we have already referred to as an axis of ambivalence: an axial relation that obtains across all scales of (semio-technical) (inter)relation - micromedio-macro - and within the mediated structure of any binary (ternary, quaternary, ...) relations whatsoever. And insofar as this transverse relation assumes the function within any structure of an "organising principle," then it is to this relation that we must firstly attribute the mechanical, "reflexive" function of agency.

As with Lévi-Strauss's "Totemic Operator" (Lévi-Strauss 1968: 152-153) - which describes the underwriting mechanism of totemic classification in so-called primitive societies (a generalised network of transverse relations between subject-object, species-genera, concept and representation, etc.) - transversality implies a broadly cybernetic 
conception of signifying structures, which posits the relativised organisation and interrelational event-states of "sign constellations" as a form of global agency. In other words, agency is thus situated not as an epiphenomenon of neuro-biological or other analogous processes, but a mechanism inherent to structuration that both "constitutes" and operates the relations in a network of potential signs, constellated around an axis of ambivalence that is also an "horizon" of signifying possibility.

Such constellational functions have been referred to by Gerald Edelman and Giulio Tononi (2000) as "dynamic functional clusters", and have been described in terms of recursive or dynamic systems generally, including the dissipative electrochemical activity of intercommunicating neurons in the human brain. Transversality has for a long time characterised investigations into some branches of neuroscience and artificial intelligence, as well as information technology, systems theory and hypertext. As a "means" of describing cognitive event-states, the virtue of transversality lies in the necessity of accounting for the materiality of any "phenomenon of consciousness" based upon a structural understanding of how the "signs" of the neuronal semiosphere relate to each other as well as to signs "apprehended" in the otherwise external world; i.e. between so-called "mental events" and "experienced events." The statistically overwhelming character of interactional possibilities represented by the transverse structures of neurological activity, with its assumed mind-orientated teleologies, suggests stochastically patterned "emergent" regularities which in turn point towards a generalised probability, affective of complex structural dynamics, and hence of the "anatomical constraints", upon which semiosis is said to be "modelled". In other words, it is precisely the "semiotic effect" of transversality upon which the assumed paradigmatic model-image of semiosis devolves: not as a first principle revealed through a process of derivation, but as the recursion of an arche-technics or ambivalence at the "origin" of the phenomenon of consciousness.

According to Favareau, the number of possible interactive connections between neurons in a human brain is estimated to exceed $10^{79}$. "Of these interactional possibilities", he points out, "the ratio between the statistically average 1 million motor neurons, 10 million sensory neurons, and 100 billion interneurons is a mediation-heavy 1:100,000:10" (Favareau 2002: 64). It is not a matter, however, of viewing this ratio as 
marking an empirical limit to, for example, a reduction to an "objectstate" of the neural network (as though it were a cause in its own right), but rather of recognising that the ratio of interactional possibilities is instead a characteristic of a generalisable event-state that necessarily remains in no way "ontologically 'fixed"" (Favareau 2002: 81). For Floyd Merrell, the transverse relation multiplied across the constellation of neurological micro- and macro-events, may be "represented" in the ambivalent figure of a significatory vortex, as a metaphor of agency or "dynamic mediation" inscribing a probabilistic network of sign operations whose structure may be broadly defined as semio-textual. "The "vortex'," Merrell suggests, "is the composite of all unactualised signs. It is, so to speak, the 'emptiness', the sheer possibility of anything and everything" (Merrell 2001: 394). The universal characteristic of possibility alluded to here simultaneously inscribes itself as a "zero-dimensionality", whereby the "vortex" mediates any relation whatsoever, as the figure of an arche-technics in advance of all signifying relations. But the dynamic interval represented by this "zero dimensionality" can also be regarded as a gradient of dissipation, or entropic spiral, in the sense that the vortex describes an engine of possibilities - i.e. it constitutes a mechanism of systemic ambivalence. This zero dimensionality "generalises" the axial relation outlined previously, with regard to the quasi-unicity of binary sign structures. As the locus of a differential interstice, it is taken to represent an "'emptiness' giving rise to the emergence of the sign, of all signs, of all that is becoming" (Merrell 2001: 395) - approximating one aspect of what, elsewhere, we have already termed vortext (as a generalised techne of semiosis).

This complex of discursive relations - here between ambivalence, interstice, constellation, transversal, vortext - may be said to describe a generalised movement of "equivalence across contiguity" of the type $S=P$ (subject, predicate), or $S / s$ (according to the Saussurean algorithm of the signifier/signified relation), whereby the advent of semiosis remains both topical and above all tropic (metaphor, metonymy) - a movement of periodicity across a non-periodic interval. As Norbert Wiener notes, recursive phenomena are "characterised by an invariance with respect to a shift of origin in time" (Wiener 1961: viii-ix), and in this sense, any properly "binary relation" whatsoever may be said to be affective of "communication" (with-out correspondence). Only in this way can the semiosphere "be regarded as a gen- 
erator of information" (Lotman 1990: 127) (rather than as a mere epiphenomenon, e.g. of semiotic "paradeigmata") — congruent on the macro-scale with the micro-scale operations of a sign generative of signs; Bateson's "difference that makes a difference" — wherein material effects of transmission accede to systematisation on the basis of a generalised techne of possibility, or techno-genesis, rather than describing a mere formalism from which "consequences" and "predictions" of various kinds might be deduced. Moreover, it is necessary to recognise that such mechanistic configurations and processes - including all forms of transduction, mediation or "communication" (as a phenomenon of ambivalence) - are therefore conditional for any assumption of semiotic possibility tending towards an event-state of semiosis.

\section{References}

Bateson, Gregory 1973. Steps to an Ecology of Mind. St Albins: Paladin.

Deely, John 2004. Sebeok Memorial Lecture. International Association for Semiotic Studies World Congress, Lyon. Manuscript.

Edelman, Gerald; Tononi, Giulio 2000. A Universe of Consciousness: How Matter Becomes Imagination. New York: Basic Books.

Everdell, William R. 1997. The First Moderns: Profiles in the Origins of Twentieth-Century Thought. Chicago: University of Chicago Press.

Favareau, Donald 2002. Beyond self and other: On the neurosemiotic emergence of intersubjectivity. Sign Systems Studies 30(1): 57-100.

Lévi-Strauss, Claude 1968. The Savage Mind. Chicago: Chicago University Press.

Lotman, Yuri M. 1990. Universe of the Mind: A Semiotic Theory of Culture. (Shukman, Ann, trans.) Bloomington: Indiana University Press.

Luure, Andres 2002. Understanding life: Trans-semiotic analogies. Sign Systems Studies 30(1): 315-325.

Merrell, Floyd 2001. Lotman's semiosphere, Peirce's categories, and cultural forms of life. Sign Systems Studies 29(2): 385-415.

Peirce, Charles Sanders 1955. Philosophical Writings. Buchler, Justus (ed.). New York: Dover.

Sebeok, Thomas A. 2001. Global Semiotics. Bloomington: Indiana University Press.

Sebeok, Thomas A.; Danesi, Marcel 2000. The Forms of Meaning: Modelling Systems Theory and Semiotic Analysis. Berlin: Mouton de Gruyter.

Wiener, Norbert 1961. Cybernetics, or Control and Communication in the Animal and the Machine. Cambridge: MIT. 


\section{Из материальности в систему}

В статье рассматривается соотношение материальности (предметности) со структурой и с явлениями обозначения (или с семиозисом). Исследуются как статус семиозиса по отношению к человеку (или шире - “органическому умвельту”) и к “нулевой степени” материальности, так и связанные с этой проблемой точки зрения и выводы (на основе текстов Пирса, Лотмана и Себеока). Подвергается сомнению классификация, очерчивающая семиозис без учета динамических систем. Исходя из постулатов нейросемиотики обосновывается необходимость рассматривать семиозис как общую характеристику систем и развивать понятие обозначения как основу, делающую возможными динамические структуры.

\section{Materiaalsusest süsteemiks}

Artikkel üritab käsitleda materiaalsuse suhet struktuuriga ja tähendustumise (semioosi) nähtustega. Vaadeldakse semioosi staatust inimese (või laiemalt orgaanilise eluilma) ning ainelise "null-astme" suhtes, sellega seotud põhjenduskäike ja järeldusi (C. Peirce'i, J. Lotmani ja T. Sebeoki põhjal). Seatakse kahtluse alla klassifikatsioon, mis piiritleb semioosi, arvestamata seejuures dünaamilisi süsteeme. Neurosemiootikast lähtuvalt põhjendatakse vajadust käsitleda semioosi kui süsteemidele üldist omadust ning arendada tähendustumise mõistet kui alust, mis teeb dünaamilised struktuurid kui sellised võimalikuks. 